unlikely that women would "overdose" on hormones. Because $2-3 \%$ of women using emergency hormonal contraception will become pregnant fears have been raised about teratogenicity. Evidence suggests that these steroids taken before implantation do not affect fetal development, ${ }^{8}$ but little is known about their effects if pregnancy is already established.

Given that emergency hormonal contraception seems an effective treatment that may be used safely in all but a very few situations, why should it not be more widely available? There are several ways in which this could be achieved. Nurses trained in family planning could prescribe emergency contraception. High street pharmacies offer even greater accessibility, which is why a change of category from prescription only to pharmacy has been proposed.

Ready access to the product would not mean that couples would be denied sympathetic professional advice and follow up if they wanted them. Certainly, potential users need to be well informed, ${ }^{910}$ and a recent health education campaign has been launched to improve public knowledge. But even the simplest means of spreading information may be blocked by fears about legal and ethical implications. ${ }^{11}$ Studies are under way to determine whether increasing the accessibility of emergency contraception reduces the incidence of unplanned pregnancy. As evidence gathers it will be hard to see why we need to exert so much medical control.

JEANETTE CAYLEY

Women's Services,

Featherstone Road Clinic,

Southall UB2 5BQ

1 Yuzpe AA, Lancee WJ. Ethinyl estradiol and dl-norgestrel as a postcoital contraceptive. Fertil Steril 1977;28:932-6.

2 Drife JO. Deregulating emergency contraception. BMF 1993;307:695-6.

3 Trusseli J, Stewart F. The effectiveness of postcoital hormonal contraception. Fam Plann Perspect 1992;24:262-4.

Webb A, Morris J. Practice of postcoital hormonal contraception-the results of a national survey. Brf Family Planning 1993;18:113-8.

5 Paintin D, ed. The provision of emergency contraception. London: Royal College of Obstetricians and Gynaecologists Press, 1995.

6 Kubba A A. Emergency contraception-guidelines for doctors. London: Faculty of Family Planning and Reproductive Health Care of the Royal College of Obstetricians and Gynaecologists, 1995.

7 Kubba A A, Guillebaud J. Case of ectopic pregnancy after postcoital contraception with ethinyloestradiol-levonorgestrel. BMF 1983;287:1343-4.

8 Cardy G. Work in progress - a survey of pregnancies after failed coital contraception. Br $\mathcal{G}$ Family Planning (in press).

9 Whitlow BJ, Desmond N, Hay P. Pregnant teenagers and contraception. BMF 1995;311:806.

10 Randall S, Lewis C. Pregnant teenagers and contraception. BMF 1995;311:807.

11 Bromham D. Contraception. In: Clements $\mathrm{R}$, ed. Safe practice in obstetrics and gynaecology. A medicolegal handbook. Edinburgh: Churchill Livingstone, 1994:381-95.

\title{
Angiotensin converting enzyme genotypes and disease
}

\section{Conflicting results from research leave the picture unclear}

Ischaemic heart disease has both environmental and genetic influences, but research has concentrated on the environmental angle. The main modifiable risk factors have been identified and preventive measures introduced with substantial success. Our knowledge of genetic factors has yet to be established in the same ways. The idea of routine tests evaluating genetic risk factors seems appealing but it has not been feasible. Test results could not at present provide a clinician with more than confirmation of a positive family history as an indicator of increased susceptibility to the disease.

The picture has changed with recent reports that a genotype of the angiotensin converting enzyme (ACE) gene may be a risk factor for ischaemic heart disease. ${ }^{12}$ These studies show the potential of modern molecular biology as a research tool for establishing genetic risk factors for cardiovascular diseases. Moreover, in this case a treatment-angiotensin converting enzyme inhibition-is available and may prove useful for those at risk. As yet, however, the predictive utility of the data from genetic and epidemiological studies remains uncertain.

A report in Nature by Cambien et al first raised the possibility of an association between ACE gene polymorphism and increased risk for myocardial infarction in relatively homogeneous groups of French and Irish men. This was a retrospective case control comparison of men studied three to nine months after acute myocardial infarction. ${ }^{1}$ The gene polymorphism is due to the presence (insertion or $\mathrm{I}$ ) or absence (deletion or $\mathrm{D}$ ) of a 287 base pair sequence in a noncoding section of the ACE gene. The DD genotype was found in $32.3 \%$ of patients and $27 \cdot 3 \%$ of controls and was associated. with a $34 \%$ (adjusted odds ratio 1.34) excess risk for acute myocardial infarction when compared with that for patients with the other two genotypes ID and II. The association seemed particularly strong in a subgroup with an overall low risk from conventional factors (adjusted odds ratio $3 \cdot 2$ ). The DD genotype was also associated with higher mean plasma concentrations of angiotensin converting enzyme- suggesting that the increased risk from this genotype may result from raised concentrations of angiotensin converting enzyme and associated higher concentrations of angiotensin II.

The hypothesis that this genetic variation of the ACE locus could be associated with an increased risk for acute myocardial infarction was further strengthened by the observation made by the same authors of an apparent excess of both DD and ID genotypes among those having a parental history of acute myocardial infarction. ${ }^{2}$ The higher prevalence of the DD genotype or $\mathrm{D}$ allele in patients with diabetes and coronary heart disease, ${ }^{3}$ patients with hypertrophic cardiomyòpathy experiencing sudden death from cardiac causes, ${ }^{4}$ and patients with left ventricular hypertrophy ${ }^{5}$ and ischaemic and idiopathic dilated cardiomyopathy ${ }^{6}$ suggests that the $\mathrm{D}$ allele may play a part in the pathogenesis.

Unfortunately, some other studies have not confirmed the association between the DD genotype and ischaemic heart disease. $^{7-9}$ Bohn et al studied 185 men and 49 women, survivors of acute myocardial infarction, $2 \cdot 7$ years after the event. They compared the frequency of the DD genotype in this group with that of 366 controls $^{7}$ and found that it was present less often among men patients $(23 \%)$ than controls ( $35 \%$ ), but they found no difference between women patients (31\%) and controls (29\%). ${ }^{7}$ Miettinen et al found no association between ACE gene polymorphism and the risk of premature coronary heart disease. ${ }^{8}$ The frequency of DD genotype in their study was $27 \%$ in patients and $18 \%$ in controls.

The conflict between Cambien's initial report and these later studies may be explained by chance because of small sample sizes; biases in selection of subjects or controls, or both; preferential loss of DD individuals in those who have died; or differences in genetic environmental interactions, but the inconsistencies raise doubts about the predictive utility of this genotype as a risk factor for ischaemic heart disease.

These doubts have been reinforced by a recent prospective study on 1250 men with ischaemic heart disease matched with 2340 controls from the physicians' health study of 22071 men, mostly white American physicians. ${ }^{9}$ The researchers 
analysed blood samples of men taken when they entered the study - so that these included both the survivors and nonsurvivors of myocardial infarction. This is an important and essential feature not included in the other studies. The results showed no association between the $\mathrm{D}$ allele and the risk of ischaemic heart disease or myocardial infarction. The odds ratio for risk of ischaemic heart disease in the overall group of patients with the DD genotype compared to the other two genotypes (ID and II) was 1.09 (95\% confidence interval 0.92 to 1.27$)$, and for myocardial infarction was $1.08(95 \%$ confidence interval 0.85 to $1 \cdot 38$ ). These negative results could be due to the heterogeneous genetic background of this North American population, which may have been too diverse to show an association between ACE gene polymorphism and ischaemic heart disease. Other reasons could be suggested, such as that the men in this study may have been at too low overall risk. Possibly, however, there may simply be no association.

Nevertheless, the renin-angiotensin system has a crucial role in the pathogenesis of ischaemic heart disease. This is shown by the undoubted benefits of angiotensin converting enzyme inhibition in reducing ischaemic events ${ }^{1011}$ and the evidence from many laboratory and clinical studies. This clinical benefit is thought to be due either to reduced formation of angiotensin II as a result of angiotensin converting enzyme inhibition or to variations in types or responses in angiotensin II receptors. Further work from Cambien's group has suggested other reasons for the increased risk of coronary artery disease- such as a synergistic effect of the increased levels of angiotensin converting enzyme associated with the $\mathrm{D}$ allele and a polymorphism of the gene for the AT1 receptor (a subtype of angiotensin II receptors) ${ }^{12}$; or another polymorphism in the ACE gene which influences the plasma concentrations of angiotensin converting enzyme-which in turn may be an independent risk factor for myocardial infarction. ${ }^{13}$ Yet other studies have suggested that a variant of the angiotensinogen gene (T235) may play a part. ${ }^{14}$ This last genetic variant is also associated with essential hypertension in both white ${ }^{15}$ and Japanese population $\mathrm{s}^{16}$ and may potentially be concerned in several pathways leading to the pathogenesis of ischaemic heart disease.

Where do we stand? The early promise that the ACE I/D gene polymorphism would prove to be an independent risk factor for ischaemic heart disease has not been substantiated by other studies. The interaction of angiotensin converting enzyme and the renin-angiotensin system has, however, important actions on blood vessels, including modulation of the formation of the atherosclerotic plaque. At present the responsible genetic factor has not been identified, but one or more genetic risk factors or markers from the angiotensin converting enzyme renin-angiotensin systems may well be found. The genetic basis for ischaemic heart disease has always been assumed to be multifactorial.

KOON K TEO

2C2 Walter Mackenzie Centre,

Associate professor of medicine

University of Alberta Hospital,

Edmonton,

Alberta,

Canada T6G 2R7

1 Cambien F, Poirier O, Lecerf L, Evans A, Cambou J-P, Arveiler D, et al. Deletion polymorphism in the gene for angiotensin-converting enzyme is a potent risk factor for myocardial infarction. in the gene for angiotensin
Nature 1992;359:641-4.

2 Tiret L, Kee F, Poirier O, Nicaud V, Lecerf L, Evans A, et al. Deletion polymorphism in angiotensin-converting enzyme gene associated with parental history of myocardial infarction. Lancet 1993;341:991-2.

3 Ruiz J, Blanche H, Cohen N, Velho G, Carnbien F, Cohen D, et al. Insertion/deletion polymorphism of the angiotensin-converting enzyme gene is strongly associated with coronary heart disease in non-insulin-dependent diabetes mellitus. Proc Natl Acad Sci 1994;91:3662-5.

4 Marian AJ, Yu Q-T, Workman R, Greve G, Roberts R. Angiotensin-converting enzyme polymorphism in hypertrophic cardiomyopathy and sudden cardiac death. Lancet 1993;342: 1085-6.

5 Schunkert H. Hense H-W, Holmer SR, Stender M, Perz S, Keil U, et al. Association between a deletion polymorphism of the angiotensin-converting-enzyme gene and left ventricular a deletion polymorphism of the angioten.

6 Raynolds MV, Bristow MR, Bush EW, Abraham WT, Lowes BD, Zisrnan LS, et al. Angiotensinconverting enzyme DD genotype in patients with ischaemic or idiopathic dilated cardiomyopathy. Lancet 1993;342:1073-5.

7 Bohn M, Berge KE, Bakken A, Erikssen J, Berg K. Insertion/deletion (I/D) polymorphism at the locus for angiotensin 1-converting enzyme and myocardial infarction. Clin Genet 1993;44:292-7.

8 Miettinen HE, Korpela K, Hamalainen L, Kontula K. Polymorphisms of the apolipoprotein and angiotensin converting enzyme genes in young North Kaelian patients with coronary heart disease. Hum Genet 1994;94:189-92.

9 Lindpaintner K, Pfeffer MA, Kreutz R, Stampfer MJ, Grodstein F, LaMotte F, et al. A prospective evaluation of an angiotensin-converting-enzyme gene polymorphism and the risk of ischemic heart disease. N Engl f Med 1995;332:706-11.

10 Yusuf S, Pepine CJ, Garces C, Pouleur H, Salem D, Kostis J, et a1. Effect of enalapril on myocardial infarction and unstable angina in patients with low ejection fraction. Lancet 1992;340:1173-8.

11 Pfeffer MA, Braunwald E, Moye LA, Basta L, Brown EJ Jr, Cuddy TE, et al. Effect of captopril on mortality and morbidity in patients with left ventricular dysfunction after myocardial infarctionresults of the survival and ventricular enlargement trial. $N$ Engl f Med 1992;327:669-77.

12 Cambien F, Costerousse O, Tiret L, Poirier O, Lecerf L Gonzales MF, et al. Plasma level and gene polymorphism of angiotensin-converting enzyme in relation to myocardial infarction. Circulation 1994;90:669-76.

13 Tiret L, Bonnardeaux A, Poirier O, Ricard S, Marques-Vidal P, Evans A, et al. Synergistic effects of angiotensin-converting enzyme and angiotensin-II type 1 receptor gene polymorphisms on risk of myocardial infarction. Lancet 1994;344:910-3.

14 Katsuya T, Koike G, Yee TW, Sharpe N, Jackson R, Norton R, et al. Association of angiotensinogen gene T235 variant with increased risk of coronary heart disease. Lancet 1995;345:1600-3.

15 Caulfield $M$, Lavender $P$, Martin F, Munroe $P$, Lawson M, Turner $P$, et al. Linkage of the angiotensinogen gene to essential hypertension. N Engl F Med 1994;330:1629-33.

16 Hata A, Narnikawa C, Sasaki M, Sato K, Nakamura T, Tamura K. Angiotensinogen as a risk factor for essential hypertension in Japan. $\mathcal{F}$ Clin Invest 1994;93:1285-7.

\section{Postoperative shivering: the influence of body temperature}

\section{May be related more to peripheral than core temperature and can be reduced by space blankets}

Postoperative shivering is common. ${ }^{1}$ During recovery from anaesthesia increased muscular activity increases oxygen consumption as much as fivefold. Hypoxaemia, lactic acidosis, and hypercarbia may then complicate recovery from anaesthesia, ${ }^{2}$ at a time when the patient is at risk of hypoxaemia from other causes. Even without these complications patients find shivering uncomfortable, and preventing the syndrome is clearly desirable.

Why do patients shiver postoperatively? It is tempting to assume that heat loss is contributory, exacerbated by peripheral vasodilatation that in turn is induced by volatile anaesthetic agents. Normal thermogenic shivering is initiated by the hypothalamus. Temperature receptors in the skin, viscera, and various levels of the neuraxis provide information on temperature which is processed at multiple levels of the spinal cord and brain before reaching the hypothalamus. Afferent information on temperature from the head and neck reaches the hypothalamus through the trigeminal nucleus. ${ }^{34}$

Although core hypothermia is not a prerequisite for postoperative shivering, ${ }^{1}$ manipulation of thermal inputs may influence the expression of postoperative shivering. For example, applying radiant heat to the face or chest may abolish postoperative shivering without affecting core temperature..$^{5-7}$ Buggy and Hughes conducted a randomised controlled study of pre-emptive protection with a space blanket. ${ }^{8}$ Five (15\%) patients wrapped in a blanket before induction of anaesthesia shivered postoperatively, compared with $21(63 \%)$ controls. Core temperatures did not differ 